\title{
PROCESS OF BIOGAS GENERATION FROM ANAEROBIC DIGESTION OF CASSAVA PEELINGS, POULTRY DROPINGS \& BEANS WASTES
}

*Electrical/Electronic Engineering Dept, Enugu State University of Science \& Technology

Email: obiageliabba@gmail.com

** Electrical/Electronic Engineering Dept, Federal University of Technology, Owerri,

Email: ephraimnc.Okafor@ futo.edu.ng

*** Electrical/Electronic Engineering Dept, University of Nigeria, Nsukka,

Email: damian.nnadi@unn.edu.ng

****Electrical/Electronic Engineering Dept, Enugu State University of Science \& Technology

The major cause of all the negative effects of global warming, soil degradation, depletion of ozone layer, ocean level rise etc are the increased use of fossil fuels for energy generation and consumption. This trend has reached a global dimension and can no longer be over sighted. All hands are now on deck to curb this menace by finding an alternative to this fossil fuel use. Replacement of these fossil energy with an energy, that is renewable in nature and more importantly environmentally friendly is all that is required. This study investigates the production of biogas from animal and plant wastes - a renewable energy from the anaerobic digestion of three different types of biodegradable wastes (Cassava peelings and poultry droppings, Beans waste and poultry droppings, Cassava peelings and beans wastes) as an alternative to fossil fuels for energy consumption. The study was carried out using a $0.1 \mathrm{~m}^{3}$ capacity biogas digester constructed to investigate the anaerobic digestion in generating biogas. The experiment was batch operated and daily gas yield from the plant was monitored for 30 days. During this period, temperature, pressure and $\mathrm{pH}$ of the slurry were monitored. Cassava peelings and poultry dropping generated the highest maximum biogas of $0.035 \mathrm{~m}^{2} / \mathrm{kg} /$ day at a $\mathrm{pH}$ value of 7.35 on the $19^{\text {th }}$ day. This was followed by poultry droppings and beans mixture. Cassava peelings and beans waste had the least volume of biogas. This treatise assets that biogas is not only a renewable energy source but has a dual function of waste management in the course of its production.

Keywords: Biogas, biodegradable, Renewable energy, Anaerobic Digestion, Waste, Fossil

\section{INTRODUCTION}

Three major challenges to any nation and the world in general today are rise in energy need of the citizens, waste management and problems arising from environmental degradation such as green house effect, deforestation, desertification, flooding, global warming etc. These aforementioned problems are directly or indirectly linked to the use of energy sourced from fossils. The singular solution to these problems is seeking alternative sources of renewable and environmentally friendly energy like biogas. Biogas is produced in biogas plants by the bacterial degradation of biomass [1]. Biogas is typically composed of 50\% - 75\% Methane and $25 \%-50 \%$ carbon dioxide. Other components of biogas are water $\left(\mathrm{H}_{2} \mathrm{O}\right)$, Oxygen $\left(\mathrm{O}_{2}\right)$ and traces of sulphur $\left(\mathrm{S}_{2}\right)$ and hydrogen sulphide $\left(\mathrm{H}_{2} \mathrm{~S}\right)$ [1]. In Nigeria, there are abundant of wastes arising from the domestic and agricultural sources of which the potential has not been 
tapped [2,3]. A look around every city in Nigeria shows enormous dumps every here and there of wastes lining up everywhere and polluting the environment. These could be re-cycled and used in biogas production.

Anaerobic biodegradation of cellulose materials is a biological process, the end product of which are a methane-rich gas called biogas and spent slurry of fertilizer vale. It is a process by which organic materials such as straw, weeds, human or animal excrements, garbage, sludge, domestic sewage and organic liquid wastes from factories etc are degraded by huge number of various microbes of different functions under anaerobic conditions to yield methane in the end [4]. It is a process having the potential for sterilization which can reduce public health hazards from faecal pathogens and if applied to agricultural residues, a reduction in the transfer of fungal and plant pathogens from one year's crop to the next [5]. The earlier problems mentioned infesting nations could be easily solved by the adoption and implementation of biogas technology. This has been the goal of this research work.

\section{MATERIALS AND METHODS}

\section{A: Sample collection}

The wastes used in the testing of the digester were poultry droppings mixed with Cassava peelings, poultry droppings mixed with beans waste (these included the beans coats removed during the preparation of 'akara', infested beans removed during picking, etc). Thirdly, cassava peelings mixed with beans waste. The poultry droppings were procured from poultry farmers along Ugwogo-Nike road. They were dried and bagged dry. The cassava peelings were procured from local garri producers at Ugbo Odogwu while the beans waste was procured from 'moimoi' and 'akara' producers at eke Obinagu market. These three groupings of wastes were used in feeding the digester in the experimental anaerobic batch digestion runs.

\section{B: Slurry Preparation}

In the setup, an expected biogas production per day was fixed at 100litres. Batch operation was selected which entailed one of the procured waste mixtures at each run time. Different analysis was carried out on the feedstock to determine Carbon-Nitrogen ratio, moisture content, Carbon content, Nitrogen content, total solids, volatile solids etc. It is also pertinent to mention here that the water to waste ratio used was $2: 1$.

\section{C: Digester charging}

After measuring and mixing of the wastes, the digester was charged with wastes, the inoculums and then the calculated volume of water. Part of the waste mixture goes in first, followed by about half of the inoculums and the remaining wastes. The entire content was vigorously shaken to allow for homogeneity. The inlet pipe which has been hitherto open was closed and locked. The digester content is then allowed to undergo digestion for a retention period of 30 days with daily measurement of gas yield.

\section{RESULTS AND DISCUSSIONS}

The digester performance evaluation was carried out using the following operational parameters.

- Daily gas production measurement by downward displacement of water in the gas collector.

- Temperature changes during biogas production.

- Pressure changes during fermentation

- $\mathrm{pH}$ changes during fermentation 
Table $1-4$ below shows the data collected during the experimentation of biogas production using the designed 100 litre digester.

Table 1: Daily gas generation by the 3 different waste categories under batch Digestion

\begin{tabular}{|r|r|r|r|} 
Time(days) & $\begin{array}{r}\text { Poultry droppings \& } \\
\text { cassava peelings(litres) }\end{array}$ & $\begin{array}{c}\text { Poultry droppings \& } \\
\text { beans waste(litres) }\end{array}$ & $\begin{array}{c}\text { Beans waste \& cassava } \\
\text { peelings(litres) }\end{array}$ \\
\hline 0 & 0 & 0 & 0 \\
\hline 2 & 0 & 0 & 0 \\
\hline 4 & 0 & 0 & 0 \\
\hline 6 & 1.4 & 1.9 & 0.7 \\
\hline 8 & 2.4 & 3.3 & 6.6 \\
\hline 10 & 11.8 & 7.1 & 8.9 \\
\hline 12 & 18.8 & 8.9 & 11.8 \\
\hline 14 & 26.8 & 12.2 & 23.5 \\
\hline 16 & 34.8 & 17.9 & 25.6 \\
\hline 18 & 36.2 & 29.1 & 27.7 \\
\hline 20 & 33.8 & 28.2 & 28.2 \\
\hline 22 & 28.2 & 31 & 24 \\
\hline 24 & 29.6 & 28.2 & \\
\hline
\end{tabular}

Table 2: Temperature changes in the three categories of waste during Fermentation

\begin{tabular}{|r|r|r|r|}
\hline & \multicolumn{3}{|c|}{ Temperature $\left({ }^{\circ} \mathrm{C}\right)$} \\
\hline Time(days) & $\begin{array}{c}\text { Poultry droppings \& } \\
\text { cassava peelings }\end{array}$ & $\begin{array}{c}\text { Poultry droppings \& } \\
\text { beans waste }\end{array}$ & $\begin{array}{c}\text { Beans waste \& } \\
\text { cassava peelings }\end{array}$ \\
\hline 0 & 32.5 & 25.9 & 26.9 \\
\hline 2 & 31 & 25.2 & 27.5 \\
\hline 4 & 33 & 25 & 26.8 \\
\hline 6 & 33 & 24.6 & 26 \\
\hline 8 & 31 & 25 & 26 \\
\hline 10 & 33.5 & 26 & 27.8 \\
\hline 12 & 33 & 26.7 & 27.4 \\
\hline 14 & 33 & 25.2 & 26.5 \\
\hline 16 & 32 & 24 & 26.4 \\
\hline 18 & 32.5 & 24 & 26.7 \\
\hline 20 & 30 & 25 & 26.5 \\
\hline 22 & 31 & 24.7 & 26.9 \\
\hline 24 & 31 & 25.1 & \\
\hline
\end{tabular}

Table 3: $\mathrm{pH}$ changes during fermentation

\begin{tabular}{|r|lr|l|r|}
\hline & \multicolumn{4}{|c|}{ PRESSURE CHANGES } \\
\hline Time(days) & $\begin{array}{l}\text { Poultry droppings \& } \\
\text { beans waste }\end{array}$ & $\begin{array}{l}\text { poultry droppings } \\
\text { \&cassava peelings }\end{array}$ & $\begin{array}{l}\text { Beans waste \& } \\
\text { cassava peelings }\end{array}$ \\
\hline 0 & 6.4 & 6.6 & 6.7 \\
\hline 2 & 6.6 & 6.7 & 6.8 \\
\hline 4 & 6.7 & 9.8 & 6.9 \\
\hline
\end{tabular}




\begin{tabular}{|r|r|r|r|}
\hline \hline 6 & 6.9 & 6.9 & 7.0 \\
\hline 8 & 7.0 & 6.9 & 7.0 \\
\hline 10 & 7.1 & 7.0 & 7.2 \\
\hline 12 & 7.2 & 7.1 & 7.3 \\
\hline 14 & 7.3 & 7.2 & 7.3 \\
\hline 16 & 7.4 & 7.3 & 7.2 \\
\hline 18 & 7.2 & 7.4 & 7.2 \\
\hline 20 & 7.2 & 7.3 & 7.1 \\
\hline 22 & 7.0 & 7.2 & 7.1 \\
\hline 24 & 6.7 & 7.1 & 7.0 \\
\hline
\end{tabular}

Table 4: Pressure changes during fermentation

\begin{tabular}{|r|l|r|r|}
\hline & \multicolumn{4}{|c|}{ PRESSURE CHANGES (mmHg) } \\
\hline Time(days) & $\begin{array}{l}\text { Poultry droppings \& } \\
\text { beans waste }\end{array}$ & $\begin{array}{l}\text { poultry droppings } \\
\text { \&cassava peelings }\end{array}$ & $\begin{array}{l}\text { Beans waste \& } \\
\text { cassava peelings }\end{array}$ \\
\hline 0 & 53 & 84 & 63 \\
\hline 2 & 84 & 126 & 73 \\
\hline 4 & 84 & 117 & 73 \\
\hline 6 & 84 & 95 & 103 \\
\hline 8 & 84 & 95 & 41 \\
\hline 10 & 104 & 146 & 119 \\
\hline 12 & 126 & 166 & 145 \\
\hline 14 & 83 & 135 & 62 \\
\hline 16 & 42 & 113 & 52 \\
\hline 18 & 83 & 123 & 82 \\
\hline 20 & 63 & 104 & 21 \\
\hline 22 & 57 & 64 & 62 \\
\hline 24 & 20 & 94 & \\
\hline & & & 62 \\
\hline
\end{tabular}

\section{A: Volume of biogas produced by each waste.}

Table1 above shows the volume of biogas produced by each of the constituents of A(poultry droppings and cassava peelings), B(poultry droppings and beans waste) and $\mathrm{C}$ (cassava peelings and beans waste) within the retention period of 24 days. It could be seen that there was no biogas production in the first 5 days. This is because biogas production rate in batch condition is a function of methanogenic bacteria [6]. Maximum production of biogas was $35.2 \mathrm{l} \mathrm{kg}$ dday on the $18^{\text {th }}$ day of biodegradation in the poultry and cassava mixture. The temperature at which this maximum gas yield was attained is $32.4^{\circ} \mathrm{C}$ as seen in figure 2 . In beans waste and poultry mixture, a maximum of 331 kglday was attained while that of the mixture of cassava peelings and beans wastes yielded $28.41 \mathrm{~kg} / \mathrm{day}$ during the same period of time.

\section{B: Temperature changes during digestion of wastes.}

Temperature has been observed by most biogas researchers to be quite critical for anaerobic digester since methane producing bacteria operate most effectively at temperature of $30^{\circ} \mathrm{C}-40^{\circ} \mathrm{C}$ or $50^{\circ} \mathrm{C}-60^{\circ} \mathrm{C}$ [9]. In this study, a temperature range of $26-32.5$ was operated. The effect of temperature on the gas yield is shown in table 2. Generally, a temperature run of $25^{\circ} \mathrm{C}-45^{\circ} \mathrm{C}$ is regarded as the mesophilic fermentation temperature while 
that of $45^{\circ} \mathrm{C}-50^{\circ} \mathrm{C}$ is regarded as thermophilic. From the gas yield of the three different constituents' mixtures, it could be seen that the quality and quantity of biogas production using farm or agricultural materials are function of nature and composition of the digester feedstock. This is similar to the report of [7].

\section{$\mathrm{C}: \mathrm{pH}$ changes during digestion of wastes.}

$\mathrm{pH}$ changes in the course of this experiment are shown in table 3 . The $\mathrm{pH}$ of any medium affects microbial population and action. In the fermentation process, it affects the rate of biogas production. From table 3, it is seen that the $\mathrm{pH}$ was low at the first 6 days, dropping to below 7.0. This is sequel to the breaking down of organic matter and production of volatile fatty acids by acid forming bacteria. After the first 8 days, the acid forming bacteria were possibly dislodged by the methane forming bacteria. This informed the breaking down of acids by the methanogens to methane and the gradual rise of the $\mathrm{pH}$. From table 3 , beans waste and cassava gave a maximum $\mathrm{PH}$ of 7.4 , followed by poultry droppings and beans waste with 7.37 and lastly, 7.32 by poultry droppings and cassava. It could also be observed that between the $18^{\text {th }}$ and $20^{\text {th }}$ days of the fermentation, maximum PH was obtained. After this, a gradual drop in $\mathrm{pH}$ is seen till the end indicating once again that the methane producing bacteria has dislodged the acid forming bacteria thus inhibiting gas production.

The changes in $\mathrm{pH}$ are probably due to temperature variation or pressure of toxicants or inhibitors or both. From the result shown, biogas production continued even at $\mathrm{pH}$ of 6.7 in conformity with reports of earlier researchers. Biogas production proceeds optimally at the $\mathrm{pH}$ range between 6.4 and 7.2[8]. A decrease in $\mathrm{pH}$ values of the system below 6.5 is caused by accumulation of volatile fatty acids (VFA) whose buffer capacity is lower than the VFA. This in turn reduces the methanogens and consequently the biogas production may be interrupted [9]

It is important to maintain the $\mathrm{pH}$ of an anaerobic digester between 6 and 8 , otherwise, methanogenesis growth would be seriously inhibited [10].

\section{D: Pressure changes during the digestion of wastes.}

During the digestion process, it was noticed that there were significant changes in pressure throughout the 24 days the process was monitored. The pressure changes during the time under review in the three different categories of wastes are shown on the table 4 above.

There is a strong relationship between pressure and the gas generation in the digestion process. This is evidenced on table 4.

\section{CONCLUSIONS}

The study on the production of biogas from the digestion of mixtures of poultry droppings and cassava peelings, poultry droppings and beans waste, cassava peelings and beans waste has shown that biogas can be produced from these wastes through anaerobic digestion for biogas generation.

These wastes are readily available in our environment and can be used as source of fuel if managed well. The biogas generated contains up to $65 \%$ methane which supports combustion. It was found out that temperature fluctuations and $\mathrm{PH}$ are among the factors that affect biogas production and temperature ranges of $25^{\circ} \mathrm{C}-45^{\circ} \mathrm{C}$ also purvey mesophile thermal stage for biogas production. It has also been shown that for maximum gas generation, experimentation with various mixes is very important. Results show that mixing of nitrogen rich and carbon rich wastes at a presumed ratio produce more gas than nitrogen - nitrogen or carbon - carbon rich wastes. 
Finally, embarking on anaerobic biodegradation process on environmental pollutants for biogas production will not only lead to clean and safer environment but also reduce the use and much dependence on fossil fuels whose by-products are deforestation, desertification, erosion, global warming and flooding.

\section{REFERENCES}

[1] Arthur Wellinger, Jerry Murphy and David Baxter, (2013). The Biogas Handbook: Science Production and Application IEA Bioenergy. Woodhead Publishing Limited, 2013 p1-14.

[2] Igoni AH, Ayotamuno MJ, Ogaji SOT, Robert SD92007) Municipal Solid waste in Port Harcout Nigeria. Applied Energy 84:664-670

[3] Olounnisola A(2007) Production of Fuel Briquette from waste paper and coconut husk Admixture. Agricultural Engineering International: CIGR E-Journal.

[4] Eze J.I,Garba, B and Atiku, A(1998). The Application of biogas slurry (Biofertilizer)in crop production. Nigerian journal of Renewable Energy, Vol.1 and 2, 1997, p.22-44.

[5] Bitrus R (2001) Design of An Anaerobic Bio-Reactor for the production of methane from Solid waste Organic Matter, Dept of Agricultural and Environmental Science River State

[6] Nopharatana A., Pullammanappallil P.C. and Clarke W.P. (2007) Kinetic and dynamic modelling of batch anaerobic digestion of municipal solid waste in a stirred reactor. Waste management. 27: 595-603.

[7] Ilori O.M., Adebusoye A.S., Lawal A.K., Awotiwon A.O., (2007) Production of Biogas from Banana and Plantain Peels. Adv. Environ. Biol. 1 (1):33-38

[8] Tambuwal BM, Baki AS, Bello A, Musa AR and Bello MR, (2019) Biogas Generation using Cattle Rumen Contents, p7.

[9] Agnieszka A P, Krzysztof P, Agnisiezka W, Piotr B and Maciej Z (2018). Use of Confectionary Waste in Biogas Production by the Anaerobic Digestion Process, p3-7.

[10] Gerardi, M. H. (2003) Toxicity, in The Microbiology of Anaerobic Digesters, John Wiley \& Sons, Inc., Hoboken, NJ, USA. doi: 10.1002/0471468967.ch17 